University of Wollongong

Research Online

Faculty of Engineering and Information

Faculty of Engineering and Information

Sciences - Papers: Part B

Sciences

2019

Maximum axial load carrying capacity of Fibre Reinforced-Polymer (FRP)

bar reinforced concrete columns under axial compression

Hayder Alaa Hasan

University of Wollongong, hah966@uowmail.edu.au

M Neaz Sheikh

University of Wollongong, msheikh@uow.edu.au

Muhammad N. S Hadi

University of Wollongong, mhadi@uow.edu.au

Follow this and additional works at: https://ro.uow.edu.au/eispapers1

Part of the Engineering Commons, and the Science and Technology Studies Commons

Research Online is the open access institutional repository for the University of Wollongong. For further information contact the UOW Library: research-pubs@uow.edu.au 


\title{
Maximum axial load carrying capacity of Fibre Reinforced-Polymer (FRP) bar reinforced concrete columns under axial compression
}

\author{
Abstract \\ In this study, a new equation is proposed to compute the maximum axial load carrying capacity of FRP \\ bar reinforced concrete columns under axial compression. The equation proposed in this study was \\ critically compared with the equations proposed in the previous research studies using a wide range of \\ experimental data taken from the available literature. In general, it was found that computing the \\ contribution of the FRP longitudinal bars in concrete columns based on the modulus of elasticity \\ (stiffness) of the FRP bars provides more rational predictions than computing the contribution of the FRP \\ longitudinal bars based on the ultimate tensile strength of the FRP bars. It was also found that using a \\ concrete compressive strength-based empirical equation in estimating the axial strain in the FRP \\ longitudinal bars in concrete columns provides more accurate predictions of the contribution of the \\ longitudinal FRP bars in the axial load sustained by the FRP bar reinforced concrete columns.
}

\section{Keywords}

(frp), maximum, reinforced, axial, compression, under, columns, concrete, load, carrying, capacity, fibre, reinforced-polymer, bar

\section{Disciplines \\ Engineering | Science and Technology Studies}

\section{Publication Details}

Hasan, H., Sheikh, M. Neaz. \& Hadi, M. N. S. (2019). Maximum axial load carrying capacity of Fibre Reinforced-Polymer (FRP) bar reinforced concrete columns under axial compression. Structures, 19 227-233. 


\section{Maximum Axial Load Carrying Capacity of Fibre Reinforced-Polymer (FRP) Bar Reinforced Concrete Columns under Axial Compression}

3

4

\section{Abstract}

15

In this study, a new equation is proposed to compute the maximum axial load carrying capacity of FRP bar reinforced concrete columns under axial compression. The equation proposed in this study was critically compared with the equations proposed in the previous research studies using a wide range of experimental data taken from the available literature. In general, it was found that computing the contribution of the FRP longitudinal bars in concrete columns based on the modulus of elasticity (stiffness) of the FRP bars provides more rational predictions than computing the contribution of the FRP longitudinal bars based on the ultimate tensile strength of the FRP bars. It was also found that using a concrete compressive strength-based empirical equation in estimating the axial strain in the FRP longitudinal bars in concrete columns provides more accurate predictions of the contribution of the longitudinal FRP bars in the axial load sustained by the FRP bar reinforced concrete columns. 
Keywords:

Concrete columns; FRP bars; concentric axial load; maximum load carrying capacity

\section{Introduction}

The main function of a reinforced concrete column is to sustain axial loads with or without bending moments. The axial load carrying capacity of steel bar reinforced concrete columns decreases over the design (service) life of the concrete structures due to the corrosion of steel bars, especially in coastal regions or in harsh environments. The cost of rehabilitation and repair of deteriorated concrete structures is significantly high [1]. The National Association of Corrosion Engineers (NACE) International reported that the

United States of America spends about two billion dollars annually to replace and repair the piers of the concrete bridges and about one billion dollars annually for maintaining marine piling systems [2].

The review of the literature found that Fibre Reinforced-Polymer (FRP) composites can be used in a wide range of civil/structural applications. The FRP composites have various structural forms that can be classified into two main classes: 1) External reinforcement (FRP jacketing) and 2) Internal reinforcement (FRP reinforcing bars) [3-4]. The FRP composites including FRP bars possess many advantageous characteristics such as the resistance to the harsh environmental conditions, light weight and high tensile strength [56]. Hence, FRP bars have the potential to replace steel bars and overcome the deterioration of concrete structures associated with the corrosion of steel reinforcement. However, the use of FRP bars as reinforcement in compression concrete members is still not recommended. This is because the ultimate compressive strength of the FRP bar is considerably lower than its ultimate tensile strength [7]. Chaallal and Benmokrane [8] 
tested GFRP bars of three different diameters $(15.9,19.1$ and $25.4 \mathrm{~mm})$ and observed that the average compressive strength of the GFRP bars was $77 \%$ of the tensile strength. Kobayashi and Fujisaki [9] reported that the strength of the Aramid-FRP (AFRP), GlassFRP (GFRP) and Carbon-FRP (CFRP) bars under axial compression were about 10\%, 30$40 \%$ and $30-50 \%$ of their tensile strength, respectively. Deitz et al. [10] tested GFRP bars with a diameter of $15 \mathrm{~mm}$ under axial compression and observed that the ultimate compressive strength of the GFRP bars was approximately equal to $50 \%$ of their tensile strength.

The acceptance of FRP bars as longitudinal reinforcement in concrete compression members such as concrete columns requires the development of design guidelines. In this regard, experimental and analytical research studies were conducted to investigate and to understand the behaviour of concrete columns reinforced longitudinally with FRP bars. Generally, the load carrying capacities of the FRP bar reinforced concrete columns under concentric and eccentric axial loads are lower than the load carrying capacities of steel bar reinforced concrete columns having same dimensions and reinforced with the same longitudinal and transverse reinforcements. The reason for this is mainly attributed to the lower ultimate compressive strength and the lower modulus of elasticity of FRP bars in compression compared to those of conventional steel bars in compression [2, 11-16]. Alsayed et al. [11] reported that the direct replacement of the longitudinal steel reinforcement with an equivalent amount of GFRP reinforcement reduced the axial load carrying capacity of the concrete columns by about $13 \%$, irrespective of the type of the transverse reinforcement (steel or GFRP). Choo et al. [12] observed through an analytical study on FRP bar reinforced square concrete columns that ignoring the contribution of the longitudinal FRP bars in the compression region of the concrete columns may be overly 
conservative. Tobbi et al. [13] and Afifi et al. [14] reported that GFRP and CFRP

78 longitudinal bars can contribute up to $10 \%$ and $13 \%$ of the axial load carrying capacity of the concrete columns, respectively. Hadhood et al. [15] reported that GFRP longitudinal bars contributed about $5 \%$ of the axial load carrying capacity of GFRP bar reinforced high strength concrete (HSC) columns. A similar contribution for GFRP bars in HSC columns was also reported in Hadi et al. [16].

Due to the variances in the reported ultimate compressive strength of the FRP bars and their contribution as longitudinal reinforcement in concrete columns, no theoretical equation was recommended in the CAN/CSA S806-12 [17] or in ACI 440.1R-15 [18] to predict the maximum axial load carrying capacity of FRP bar reinforced concrete columns. Nonetheless, several theoretical equations were proposed in the previous research studies to predict the maximum axial load carrying capacity of FRP bar reinforced concrete columns. However, these equations have not been adequately assessed using a wide range of experimental data.

In this study, a new equation is proposed to predict the maximum axial load carrying capacity of concrete columns reinforced longitudinally with FRP bars. The theoretical equations, proposed in this study and in the previous studies, were critically assessed using a wide range of experimental data taken from the available literature. The observations reported in this study can help in establishing guidelines for designing FRP bar reinforced concrete compression members 
The analysis of conventional steel bar reinforced concrete members is based on several basic assumptions, which are essential to compute the load carrying capacity of these members under different loading conditions. It was reported that these assumptions might be applicable to be used for GFRP bar reinforced concrete members [12, 15, 19]. Therefore, 107 the assumptions were presented first and were used to analytically investigate the behaviour of GFRP bar reinforced circular concrete columns under concentric axial loads.

The basic assumptions are:

1. The maximum strain, $\varepsilon_{c}$, in concrete does not exceed an assumed ultimate concrete compressive strain, $\varepsilon_{c u}$.

2. A perfect bond exists at the interfaces between the GFRP bars and the surrounding concrete.

3. The axial strain in the concrete, $\varepsilon_{c}$, and the axial strain in GFRP reinforcing bars, $\varepsilon_{f}$, are equal at any concentric axial load.

\section{Maximum axial load carrying capacity of reinforced concrete columns}

This study mainly focuses on the development of a theoretical equation for predicating the maximum axial load carrying capacity of FRP bar reinforced concrete columns, which occurs when columns are subjected to pure compression loads (axial loads with zero eccentricities). The proposed equation for the maximum axial load carrying capacity of FRP bar reinforced concrete columns can be incorporated in the future design codes for composite structures. The effects of the combined axial and flexural loads on the behaviour of FRP bar reinforced concrete columns are considered beyond the scope of this study. 


\subsection{Steel bar reinforced concrete columns}

128

129

The maximum axial load carrying capacity, $P_{o}$, of conventional steel bar reinforced concrete columns under concentric axial load can be predicted using Eq. 1 [20-21].

$$
P_{o}=P_{c}+P_{b a r, s t}
$$

$P_{c}=\alpha f_{c}^{\prime}\left(A_{g}-A_{s t}\right)$

$$
P_{b a r, s t}=f_{y} A_{s t}
$$

Equation 1 represents the summation of the axial loads sustained by the concrete and steel longitudinal bars. The $P_{c}$ represents the contribution of the concrete considering the gross area of the columns $A_{g}$ as shown in Eq. 2. The $P_{b a r, s t}$ represents the contribution of the longitudinal steel bars. The $f_{y}$ and $A_{s t}$ are the yield strength and the total cross-sectional area of the longitudinal steel bars. It is noted that in Eq. 1 - Eq. 3, the effect of shear reinforcement has not been taken into account for calculating the maximum axial load carrying capacity of reinforced concrete columns under concentric axial loads [20].

The compressive strength of plain concrete in full-scale concrete columns tested under concentric axial loads is generally lower than the compressive strength of standard concrete cylinders. The differences between the compressive strength of concrete in columns and the compressive strength of standard concrete cylinders are commonly attributed to the differences in the shape, size and concrete casting process between columns and cylinders. In Eq. 2, the parameter $\alpha$ is a reduction factor that represents the ratio between the in-place compressive strength of concrete in actual concrete columns to 
152 the compressive strength of standard concrete cylinders. Extensive experimental 153 investigations were carried out on reinforced concrete columns and the parameter $\alpha$ was 154 recommended to be taken equal to 0.85 [22]. The recommended value for the parameter $\alpha$ 155 was considered in ACI 318-14 [20] to determine the contribution of the concrete in the 156 maximum axial load carrying capacity of conventional steel bar reinforced concrete 157 columns (Eq. 4).

158

159

160

$$
P_{o}=0.85 f_{c}^{\prime}\left(A_{g}-A_{s}\right)+f_{y} A_{s}
$$

\subsection{FRP bar reinforced concrete columns}

Different equations were proposed in the previous research studies to predict the maximum axial load carrying capacity of FRP bar reinforced concrete columns. It is important to note that the contribution of the concrete, in the analytically computed axial load carrying capacity of FRP bar reinforced concrete columns, remains similar in all of the proposed equations. In other words, the differences in the analytically computed values of $P_{o}$ for FRP bar reinforced concrete columns are primarily due to the different concepts adopted in different proposed equations for calculating the contribution of the FRP longitudinal bars $\left(P_{b a r, F R P}\right)$.

The compressive strength of FRP bar is considerably lower than its tensile strength and the behaviour of FRP bar under compressive loads differs significantly, as mentioned above. Hence, ACI 440.1R-06 [23] recommends not to reinforce concrete columns longitudinally with FRP bars and ACI 440.1R-15 [18] provided no recommendations in this regard. The CAN/CSA S806-12 [17] permits reinforcing concrete columns longitudinally with FRP bars. However, CAN/CSA S806-12 [17] recommends neglecting the contribution of the 
177 FRP longitudinal bars when predicting the maximum axial load carrying capacity of the 178 FRP bar reinforced concrete columns. Based on the recommendations in the CAN/CSA S806-12 [17], the maximum axial load carrying capacity of FRP bar reinforced concrete columns can be predicted using Eq. 5.

$$
P_{o}=0.85 f_{c}^{\prime}\left(A_{g}-A_{f}\right)
$$

where $A_{f}$ represents the total cross-sectional area of GFRP longitudinal bars.

However, a considerable number of research studies observed that disregarding the contribution of FRP longitudinal bars in compression, as in Eq. 5, might result in a large difference between the analytically computed and the experimentally obtained axial load carrying capacity of the FRP bar reinforced concrete columns [14, 24-25]. Therefore, two approaches were considered to compute the contribution of FRP longitudinal bars in the maximum axial load carrying capacity of FRP bar reinforced concrete columns. In the first approach, the axial load sustained by FRP longitudinal bars is calculated using the tensile strength of the FRP bars, $\alpha_{f} f_{f u} A_{f}$ (Eq. 6). In the second approach, the axial load sustained stiffness (modulus of elasticity) of the FRP bars, $\varepsilon_{f} E_{f} A_{f}$ (Eq. 7).

$$
P_{o}=0.85 f_{c}^{\prime}\left(A_{g}-A_{f}\right)+\alpha_{f} f_{f u} A_{f}
$$

$$
P_{o}=0.85 f_{c}^{\prime}\left(A_{g}-A_{f}\right)+\varepsilon_{f} E_{f} A_{f}
$$


In Eq. 6 , the $\alpha_{f}$ is a reduction factor that represents the ratio between the strength of FRP

202

203

204

205

206

207

208

209

210

211

212

213

214

215

216

217

218

219

220

221

222

223

224

225

.
bar under compression and the strength of the FRP bar under tension. Different values for $\alpha_{f}$ were recommended in the previous studies. Alsayed et al. [11] suggested taking $\alpha_{f}$ equal to 0.6. Later, Tobbi et al. [13] recommended taking $\alpha_{f}$ equal to 0.35 based on experimental observations reported in Kobayashi and Fujisaki [9]. Also, $\alpha_{f}$ was recommended to be taken equal to 0.35 in Afifi et al. [26] for GFRP bar reinforced circular concrete columns. However, for CFRP bar reinforced circular concrete columns, Afifi et al. [14] recommended taking $\alpha_{f}$ equal to 0.25 .

In Eq. 7, different values were also suggested for the axial strain in the FRP longitudinal bars, $\varepsilon_{f}$, at the maximum axial load carrying capacity of the concrete columns. Mohamed et al. [2] suggested taking $\varepsilon_{f}$ equal to 0.002 , explaining that this value $\left(\varepsilon_{f}=0.002\right)$ represents the axial strain in the FRP longitudinal bars at the initiation of the micro-cracks in the plastic stage of the concrete. However, Hadi et al. [25] recommended taking $\varepsilon_{f}$ equal to 0.003 , which represents the ultimate strain of the concrete, $\varepsilon_{c u}$.

It is obvious that different research studies proposed different equations based on a limited number of experimental data. Therefore, there is no consensus in the previous research studies on a unified equation for predicting the maximum axial load carrying capacity of FRP bar reinforced concrete columns, which may also be attributed to the variances in the response of the FRP bars under axial compression.

In this study, the axial load sustained by FRP longitudinal bars, $P_{b a r, F R P}$, was predicted based on the stiffness (modulus of elasticity) of the FRP bars because the modulus of elasticity of FRP bars in compression is approximately similar to the modulus of elasticity 
of FRP bars in tension $[8,10]$. On the other hand, the compressive strength of the FRP

227

228

229 longitudinal bars corresponding to their ultimate tensile strength tends to fluctuate significantly, depending on the manufactures and the type of the FRP bars (AFRP, GFRP and CFRP). The significant fluctuations in the compressive strength of the FRP bars can be considered one of the main reasons why different values for the reduction factor $\alpha_{f}$ were proposed in different research studies. Hence, simply changing the value of the reduction factor $\alpha_{f}$ in Eq. 6 might not provide reasonable predictions for the maximum axial load carrying capacity of FRP bar reinforced concrete columns. The axial strain in the FRP longitudinal bars $\varepsilon_{f}$ at the maximum axial load carrying capacity of the concrete columns was considered to be equal to the concrete axial strain at peak stress $\varepsilon_{c o}$. The concept adopted in this study is consistent with the third assumption in Section 2, which states that the axial strain in the concrete and the axial strain in longitudinal FRP reinforcing bars are equal at any concentric axial load. Accordingly, the maximum axial load carrying capacity of FRP bar reinforced concrete columns can be predicted using Eq. 8:

$$
P_{o}=0.85 f_{c}^{\prime}\left(A_{g}-A_{f}\right)+\varepsilon_{c o} E_{f} A_{f}
$$

Based on a considerable number of theoretical and experimental research studies, several empirical formulas were proposed in the past few decades for computing the concrete axial strain at peak stress, $\varepsilon_{c o}$. In this study, four of the available, applicable and widely accepted formulae (Eq. 9 - Eq. 12) were used to compute $\varepsilon_{c o}$ in Eq.8.

$$
\varepsilon_{c o}=735\left(f_{c}^{\prime}\right)^{0.25} \times 10^{-6}
$$




$$
\varepsilon_{c o}=0.0005\left(f_{c}^{\prime}\right)^{0.4}
$$

$$
\varepsilon_{c o}=0.0016 \exp \left(240 f_{c}^{\prime} / E_{1}\right)
$$

Equation 9 was proposed in Popovics [27] for normal strength concrete with compressive strength of up to $50 \mathrm{MPa}$. whereas Eq. 10, proposed in Wee et al. [28], covered concrete proposed in Yang et al. [30], is applicable to concrete with compressive strengths ranging between 10 and $180 \mathrm{MPa}$. Although Eq. 9 is applicable for normal strength concrete, an average difference of only $6 \%$ was observed between the values of the concrete axial strain, $\varepsilon_{c o}$, obtained from using Eq. 9 and Eq. 10. But, the values of $\varepsilon_{c o}$ obtained using Eq. 9 and

Eq. 10 were consistently below the values of $\varepsilon_{c o}$ obtained using Eq. 11 and Eq. 12, especially for concrete having compressive strength greater than $100 \mathrm{MPa}$.

\section{Critical assessment of the proposed equations}

268

The equation proposed in this study was critically reviewed using a wide range of published experimental data (Table 1). The equation proposed in Tobbi et al. [9] was also examined. Hadi et al. [25] recommended assuming $\varepsilon_{f}$ equal to $\varepsilon_{c u}$. The equation proposed in Hadi et al. [25] was also assessed, firstly by taking $\varepsilon_{c u}$ equal to 0.003 as defined in the ACI 318-14 [20] and secondly by taking $\varepsilon_{c u}$ equal to 0.0035 as defined in the CSA A23.3$14[21]$. 
275 Table 2 presents the ratios between the analytically predicted and the experimentally 276 obtained axial load carrying capacity $\left(P_{o} / P_{\text {exp. }}\right)$ for the experimentally tested specimens

277 presented in Table 1 . The analytically predicted axial load carrying capacity, $P_{o}$, was 278 calculated using either Eq. 6 by taking $\alpha_{f}$ equal to 0.35 , as recommended in Tobbi et al.

279 [13] or using Eq. 8, in which the value of $\varepsilon_{c o}$ was either computed using the formulas 280 presented in the above section (Eq. 9 - Eq. 12) or taken equal to $\varepsilon_{c u}(0.003$ or 0.0035 as 281 defined in the ACI 318-14 [20] and CSA A23.3-14 [21], respectively).

282

In Table 2, the accuracy of the equations proposed in this study and in the previous research studies in predicting the maximum axial load carrying capacity of FRP bar reinforced concrete columns was examined using four different mathematical measurements: Mean value $(\mu)$; Standard Deviation $(S D)$; Coefficient of Variation $(C O V)$ and the Mean Absolute Percentage Error $(M A P E)$. The Mean value $(\mu)$ represents the central value of the discrete set of $P_{o}$ values. The Standard Deviation $(S D)$ was used to quantify the level of variation (dispersion) for the values of $P_{o}$. High standard deviation indicates that the predicted axial load carrying capacities of the FRP bar reinforced concrete specimens are spread out over a wider range of values (less reliable) and vice versa. The standard deviation $(S D)$ indicates to an absolute term of how much the values of $P_{o}$ are spread. The values of $P_{o}$ were then assessed as a percentage of how far away they spread from their mean value using the Coefficient of Variation $(\mathrm{COV})$. The lower the $C O V$, the lower the dispersion of $P_{o}$ is from the mean value. The Mean Absolute Percentage Error $(M A P E)$ is also used as a measurement to examine the accuracy of the equation proposed in this study and the equations proposed in previous research studies for the maximum axial load carrying capacities of the FRP bar reinforced concrete columns. The lower the MAPE, the better predictions provided by the proposed equation. 
Table 2 presents the comparison between the experimental and theoretical axial load carrying capacity of FRP bar reinforced concrete columns. It was found that Eq. 8, in which the contribution of the FRP bars is computed based on the stiffness of the FRP bars, provides more reliable and safer predictions for $P_{o}$ compared to Eq. 6, in which the contribution of the FRP bars is computed using the tensile strength of the FRP bars. This might be mainly attributed to the fact that the modulus of elasticity of the FRP bars in tension is approximately equal to the modulus of elasticity of FRP bars in compression, while there is a large difference between the tensile and the compressive strength of the FRP bars. It was also found that, in Eq. 8, the use of the formula proposed by Legeron and Paultre [29] (Eq. 11) in computing $P_{b a r, F R P}$ provides lower discrepant values of $P_{o}$, as shown in Fig. 1, giving a standard deviation and a coefficient of variation of 0.071 and 7.71, respectively. On the other hand, taking the concrete axial strain at peak stress $\varepsilon_{c o}$ equal to 0.003 when computing $P_{b a r, F R P}$ provided predictions for $P_{o}$ with the lowest percentage of error giving a mean absolute percentage error MAPE of 7.542. Furthermore, with high $S D$ and $C O V$ of 0.082 and 8.47, respectively (Fig. 1).

Figure 2 shows the relationship between the $\left(P_{o} / P_{\text {exp. }}\right)$ for the specimens presented in Table 2 and the compressive strength of the concrete. In Fig. 2, the $P_{o}$ was either obtained and Paultre [29]. 
324 Assuming $\alpha_{f}$ equal to 0.35 (Eq. 6), as recommended in Tobbi et al [13], over-predicts the 325 axial load carrying capacity for most of the FRP bar reinforced NSC and HSC columns 326 presented in Table 1, as shown in Fig 2a. However, using Eq. 8, assuming $\varepsilon_{c o}$ equal to 3270.003 for computing the contribution of the FRP bar over-predicts the axial load carrying capacity of $23 \%$ of the FRP bar reinforced specimens. But in general it provides reasonable predictions with mean value $\mu$ for $\left(P_{o} / P_{\text {exp. }}\right)$ of 0.95 . On the other hand, using Eq. 8, considering the formula proposed in Legeron and Paultre [29] (Eq. 11) for $\varepsilon_{c o}$ in computing the contribution of the FRP bar over-predicts the axial load carrying capacity of only $6 \%$ of the total number of the specimens presented in Table 2 with a mean value $\mu$ for $\left(P_{o} / P_{\text {exp. }}\right)$ of 0.93 , hence, it provides reliable and safe prediction for nearly all the FRP bar reinforced NSC and HSC column specimens (Fig 2d).

\section{Conclusions}

The present study proposes a theoretical equation for predicting the maximum axial load carrying capacity of FRP bar reinforced concrete columns. In the proposed equation, the contribution of the FRP longitudinal bars was computed based on the axial strain and the stiffness (modulus of elasticity) of the FRP longitudinal bars. An empirical equation based on the concrete compressive strength was developed to compute the axial strain in the FRP longitudinal bars at the maximum axial load carrying capacity of the FRP bar reinforced concrete columns. The proposed equation was validated using a large set of experimental data available in the literature. The equation proposed in this study provided more accurate and safe predictions of the experimentally tested FRP bar reinforced columns. The theoretical equation proposed in this study can be easily applied in predicting the axial load carrying capacity of normal strength and high strength concrete columns reinforced with different types of FRP bars. 


\section{Acknowledgments}

350

351

352

353

354

355

356

357

358

359

360

361

362

363

364

365

366

367

368

369

370

371

The authors gratefully acknowledge the University of Wollongong for providing all the required facilities to accomplish this study. The first author would also like to acknowledge the Iraqi Government for the support of his full Ph.D. scholarship.

\section{References}

[1] Sheikh, M. N., and Legeron, F., (2014), "Performance based seismic assessment of bridges designed according to Canadian Highway Bridge Design Code," Canadian Journal of Civil Engineering, Vol. 41, No. 9, pp. 777-787.

[2] Mohamed, H., Afifi, M., and Benmokrane, B., (2014), "Performance evaluation of concrete columns reinforced longitudinally with FRP bars and confined with FRP hoops and spirals under axial load," Journal of Bridge Engineering, Vol. 19, No. 7, 04014020 pp.

[3] Zaman, A., Gutub, S. A., and Wafa, M. A., (2013), “A review on FRP composites applications and durability concerns in the construction sector," Journal of Reinforced Plastics and Composites, Vol. 32, No. 24, pp. 1966-1988.

[4] Mukhopadhyay, T., Dey, T. K., Chowdhury, R., Chakrabarti, A., and Adhikari, S., (2015), “Optimum design of FRP bridge deck: an efficient RS-HDMR based approach," Structural and Multidisciplinary Optimization, Vol. 52, No. 3, pp. 459477.

[5] Li, X., Lu, J., Ding, D.-D., and Wang, W., (2017), “Axial strength of FRP-confined rectangular RC columns with different cross-sectional aspect ratios," Magazine of Concrete Research, Vol. 69, No. 19, pp. 1011-1026. 
[6] Karsh, P. K., Mukhopadhyay, T., and Dey, S., (2018), "Spatial vulnerability analysis for the first ply failure strength of composite laminates including effect of delamination," Composite Structures, Vol. 184, pp. 554-567.

[7] ACI (American Concrete Institute), (2007), "Report on Fiber-Reinforced Polymer (FRP) reinforcement concrete structures," ACI 440R-07, Farmington Hills, MI, 100 pp.

[8] Chaallal, O., and Benmokrane, B., (1993), "Physical and mechanical performance of an innovative glass-fiber-reinforced plastic rod for concrete and grouted anchorages," Canadian Journal of Civil Engineering, Vol. 20, No.2, pp. 254-268.

[9] Kobayashi, K., and Fujisaki, T. (1995), “Compressive behavior of FRP reinforcement in non-prestressed concrete members," Non-Metallic (FRP) Reinforcement for Concrete Structures: Proceedings of the Second International RILEM Symposium, CRC Press, 267 pp.

[10] Deitz, D., Harik, I., and Gesund, H., (2003), "Physical properties of glass fiber reinforced polymer rebars in compression," Journal of Composites for Construction, Vol. 7, No. 4, pp. 363-366.

[11] Alsayed, S. H., Al-Salloum, Y. A., Almusallam, T. H., and Amjad, M. A., (1999), "Concrete columns reinforced by GFRP rods," 4th Int. Symp. on Fiber-Reinforced Polymer Reinforcement for Reinforced Concrete Structures SP-188, C. W. Dolan, S. H. Rizkalla, and A. Nanni, eds., American Concrete Institute, Farmington Hills, MI, 103-112 pp.

[12] Choo, C. C., Harik, I. E., and Hans, G., (2006), "Strength of rectangular concrete columns reinforced with fiber-reinforced polymer bars," ACI Structural Journal, Vol. 103, No. 3, pp. 452-459. 
[13] Tobbi, H., Farghaly, A. S., and Benmokrane, B., (2012), "Concrete columns reinforced longitudinally and transversally with glass fiber-reinforced polymer bars," ACI Structural Journal, Vol. 109, No. 4, pp. 551-558.

[14] Afifi, M., Mohamed, H., and Benmokrane, B. (2013a). "Strength and axial behavior of circular concrete columns reinforced with CFRP bars and spirals." Journal of Composites for Construction, Vol. 18, No. 2, 04013035 pp.

[15] Hadhood, A., Mohamed, H. M., and Benmokrane, B., (2016), "Experimental study of circular high-strength concrete columns reinforced with GFRP bars and spirals under concentric and eccentric loading," Journal of Composites for Construction, Vol. 21, No. 2, 04016078 pp.

[16] Hadi, M. N. S., Hasan, H. A., and Sheikh, M. N., (2017), "Experimental investigation of circular high-strength concrete columns reinforced with glass fiber-reinforced polymer bars and helices under different loading conditions," Journal of Composites for Construction, Vol. 21, No. 4, 04017005 pp.

[17] CSA (Canadian Standards Association), (2012), "Design and construction of building components with fiber reinforced polymers," CAN/CSA S806-12, Rexdale, ON, Canada.

[18] ACI (American Concrete Institute). (2015), "Guide for the design and construction of structural concrete reinforced with FRP bars," ACI: 440.1R-15, Farmington Hills, MI.

[19] Hasan, H. A., Sheikh, M. N., and Hadi, M. N. S., (2017), "Performance evaluation of high strength concrete and steel fibre high strength concrete columns reinforced with GFRP bars and helices," Construction and Building Materials, Vol. 134, pp. 297-310. 
419 [20] ACI (American Concrete Institute), (2014), "Bulding code requirements for structural concrete," ACI: 318M-14, Farmington Hills, MI.

421

422

423

[21] CSA (Canadian Standards Association), (2014), "Design of concrete structures," CAN/CSA-A23.3-14, Rexdale, ON, Canada, 290 pp.

[22] Lyse, I., and Kreidler, L., (1932), "Fourth progress report on column tests at Lehigh University," ACI Journal,Proceedings, V. 28, No. 1, pp. 317-346.

[23] ACI (American Concrete Institute), (2006), “Guide for the design and construction of structural concrete reinforced with FRP bars," ACI: 440.1R-06, Farmington Hills, MI.

[24] Tobbi, H., Farghaly, A. S., and Benmokrane, B., (2014), "Behavior of concentrically loaded fiber-reinforced polymer reinforced concrete columns with varying reinforcement types and ratios," ACI Structural Journal, Vol. 111, No. 2, pp. 375386.

[25] Hadi, M., Karim, H., and Sheikh, M., (2016), "Experimental investigations on circular concrete columns reinforced with GFRP bars and helices under different loading conditions," Journal of Composites for Construction, Vol. 20, No. 4, 04016009 pp.

[26] Afifi, M., Mohamed, H., and Benmokrane, B., (2013b), “Axial capacity of circular concrete columns reinforced with GFRP bars and spirals," Journal of Composites for Construction, Vol. 18, No.1, 04013017 pp.

[27] Popovics, S., (1973), “A numerical approach to the complete stress-strain curve of concrete," Cement and Concrete Research, Vol. 3, No. 5, pp. 583-599.

[28] Wee, T., Chin, M. and Mansur, M., (1996), "Stress-strain relationship of highstrength concrete in compression," Journal of Materials in Civil Engineering, Vol. 8, No. 2, pp. 70-76. 


\section{4}

\section{5}

[29] Légeron, F. and Paultre, P., (2003), "Uniaxial confinement model for normal- and high-strength concrete columns," Journal of Structural Engineering, Vol. 129, No.2, pp. 241-252.

[30] Yang K-H, Mun J-H, Cho M-S, Kang THK., (2014), "Stress-strain model for various unconfined concretes in compression," ACI Structural Journal, V. 111, No. 4, pp. $819-26$.

[31] Karim, H., Sheikh, M. N., and Hadi, M. N. S., (2016), “Axial load-axial deformation behaviour of circular concrete columns reinforced with GFRP bars and helices," Construction and Building Materials, Vol. 112, pp. 1147-1157.

[32] Hales, T. A., Pantelides, C. P., and Reaveley, L. D., (2016), "Experimental evaluation of slender high-strength concrete columns with GFRP and hybrid reinforcement," Journal of Composites for Construction, Vol. 20, No. 6, 04016050 pp.

[33] Hadhood, A., Mohamed, H. M., Ghrib, F., and Benmokrane, B., (2017), "Efficiency of glass-fiber reinforced-polymer (GFRP) discrete hoops and bars in concrete columns under combined axial and flexural loads," Composites Part B: Engineering, Vol. 114, pp. 223-236.

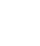

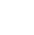

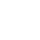

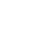

.

.

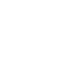

6 
469 Table 1: Experimental data of FRP bar reinforced concrete columns taken from available 470 previous research studies.

471 Table 2: Comparison between the experimental and theoretical axial load carrying capacity 472 of FRP bar reinforced concrete columns available in the previous research studies

473

474

475

476

477

478

479

480

481

482

483

484

485

486

487

488

489

490

491

492 
494 Fig. 1: Experimental versus predicted axial load carrying capacity of FRP bar reinforced

495 concreter columns obtained using: a) Eq. $6\left(\alpha_{f}=0.35\right) ;$ b) Eq. $8\left(\varepsilon_{c o}=0.003\right)$; c) Eq. 8

496 $\left(\varepsilon_{c o}=0.0035\right)$ and d) Eq. $8\left(\varepsilon_{c o}=0.005\left(f_{c}^{\prime}\right)^{0.4}\right)$.

497 Fig. 2: The relationship between $P_{o} / P_{\text {exp }}$ of the FRP bar reinforced concrete column and 498 the compressive strength of the concrete $f_{c}^{\prime}$. Note: $P_{o}$ were obtained using: a) Eq. $6\left(\alpha_{f}=\right.$

499 $0.35)$; b) Eq. $8\left(\varepsilon_{c o}=0.003\right)$; c) Eq. $8\left(\varepsilon_{c o}=0.0035\right)$ and d) Eq. $8\left(\varepsilon_{c o}=0.005\left(f_{c}^{\prime}\right)^{0.4}\right)$.

500

501

502

503

504

505

506

507

508

509

510

511

512

513

514

515

516

517 
Table 1: Experimental data of FRP bar reinforced concrete columns taken from available previous research studies.

\begin{tabular}{|c|c|c|c|c|c|c|c|c|c|}
\hline \multirow[t]{2}{*}{ Research study } & \multicolumn{3}{|c|}{ Specimen cross-section } & \multicolumn{5}{|c|}{ FRP longitudinal reinforcement } & \multirow{2}{*}{$\frac{\text { Concrete }}{f_{c}^{\prime}(\mathrm{MPa})}$} \\
\hline & Specimen & Column shape & Dimensions* ${ }^{*}(\mathrm{~mm})$ & Type & No. of bars & Diameter $(\mathrm{mm})$ & $f_{f u}(\mathrm{MPa})$ & $E_{f}(\mathrm{MPa})$ & \\
\hline \multirow{9}{*}{ Afifi et al. [14] } & SP-1 & Circular & 300 & CFRP & 6 & 12.7 & 1899 & 140000 & 42.9 \\
\hline & SP-2 & Circular & 300 & CFRP & 10 & 12.7 & 1899 & 140000 & 42.9 \\
\hline & SP-3 & Circular & 300 & CFRP & 10 & 12.7 & 1899 & 140000 & 42.9 \\
\hline & $\mathrm{SP}-4$ & Circular & 300 & CFRP & 10 & 12.7 & 1899 & 140000 & 42.9 \\
\hline & SP-5 & Circular & 300 & CFRP & 10 & 12.7 & 1899 & 140000 & 42.9 \\
\hline & SP-6 & Circular & 300 & CFRP & 10 & 12.7 & 1899 & 140000 & 42.9 \\
\hline & SP-7 & Circular & 300 & CFRP & 10 & 12.7 & 1899 & 140000 & 42.9 \\
\hline & SP-8 & Circular & 300 & CFRP & 10 & 12.7 & 1899 & 140000 & 42.9 \\
\hline & SP-9 & Circular & 300 & CFRP & 14 & 12.7 & 1899 & 140000 & 42.9 \\
\hline \multirow{9}{*}{ Afifi et al. [26] } & SP-10 & Circular & 300 & GFRP & 4 & 15.9 & 934 & 55400 & 42.9 \\
\hline & SP-11 & Circular & 300 & GFRP & 8 & 15.9 & 934 & 55400 & 42.9 \\
\hline & SP-12 & Circular & 300 & GFRP & 8 & 15.9 & 934 & 55400 & 42.9 \\
\hline & SP-13 & Circular & 300 & GFRP & 8 & 15.9 & 934 & 55400 & 42.9 \\
\hline & SP-14 & Circular & 300 & GFRP & 8 & 15.9 & 934 & 55400 & 42.9 \\
\hline & SP-15 & Circular & 300 & GFRP & 8 & 15.9 & 934 & 55400 & 42.9 \\
\hline & SP-16 & Circular & 300 & GFRP & 8 & 15.9 & 934 & 55400 & 42.9 \\
\hline & SP-17 & Circular & 300 & GFRP & 8 & 15.9 & 934 & 55400 & 42.9 \\
\hline & SP-18 & Circular & 300 & GFRP & 12 & 15.9 & 934 & 55400 & 42.9 \\
\hline \multirow{6}{*}{ Mohamed et al. [2] } & SP-19 & Circular & 300 & GFRP & 8 & 15.9 & 934 & 55400 & 42.9 \\
\hline & SP-20 & Circular & 300 & GFRP & 8 & 15.9 & 934 & 55400 & 42.9 \\
\hline & SP-21 & Circular & 300 & GFRP & 8 & 15.9 & 934 & 55400 & 42.9 \\
\hline & SP-22 & Circular & 300 & CFRP & 10 & 12.7 & 1899 & 140000 & 42.9 \\
\hline & SP-23 & Circular & 300 & CFRP & 10 & 12.7 & 1899 & 140000 & 42.9 \\
\hline & SP-24 & Circular & 300 & CFRP & 10 & 12.7 & 1899 & 140000 & 42.9 \\
\hline
\end{tabular}


Table 1: (Continued)

\begin{tabular}{|c|c|c|c|c|c|c|c|c|c|}
\hline \multirow[t]{2}{*}{ Research study } & \multicolumn{3}{|c|}{ Specimen cross-section } & \multicolumn{5}{|c|}{ FRP longitudinal reinforcement } & \multirow{2}{*}{\begin{tabular}{|c|c|} 
Concrete \\
$f_{c}^{\prime}(\mathrm{MPa})$
\end{tabular}} \\
\hline & Specimen & Column shape & Dimensions $^{*}(\mathrm{~mm})$ & Type & No. of bars & Diameter $(\mathrm{mm})$ & $f_{f u}(\mathrm{MPa})$ & $E_{f}(\mathrm{MPa})$ & \\
\hline \multirow{4}{*}{ Karim et al. [31] } & SP-25 & Circular & 205 & GFRP & 6 & 12.7 & 1600 & 66000 & 32 \\
\hline & SP-26 & Circular & 205 & GFRP & 6 & 12.7 & 1600 & 66000 & 32 \\
\hline & SP-27 & Circular & 205 & GFRP & 0 & 0 & 0 & 0 & 32 \\
\hline & SP-28 & Circular & 205 & GFRP & 0 & 0 & 0 & 0 & 32 \\
\hline Hales et al. [32] & SP-29 & Circular & 305 & GFRP & 6 & 16 & 715 & 44000 & 90 \\
\hline \multirow{2}{*}{ Hadhood et al. [15] } & SP-30 & Circular & 305 & GFRP & 8 & 15.9 & 1289 & 54900 & 70.2 \\
\hline & SP-31 & Circular & 305 & GFRP & 12 & 15.9 & 1289 & 54900 & 70.2 \\
\hline Hadhood et al. [33] & $\mathrm{SP}-32$ & Circular & 305 & CFRP & 8 & 15.9 & 1680 & 141000 & 35 \\
\hline \multirow{2}{*}{ Hadi et al. [16] } & SP-33 & Circular & 210 & GFRP & 6 & 12.7 & 1548 & 67800 & 85 \\
\hline & SP-34 & Circular & 210 & GFRP & 6 & 12.7 & 1548 & 67800 & 85 \\
\hline \multirow{4}{*}{ Tobbi et al. [13] } & SP-35 & Square & $350 \times 350$ & GFRP & 8 & 19.1 & 728 & 47600 & 33 \\
\hline & SP-36 & Square & $350 \times 350$ & GFRP & 12 & 15.9 & 751 & 48200 & 33 \\
\hline & SP-37 & Square & $350 \times 350$ & GFRP & $4+4$ & $12.7,15.9$ & 1040,751 & 46300,48200 & 33 \\
\hline & SP-38 & Square & $350 \times 350$ & GFRP & 8 & 12.7 & 1040 & 46300 & 33 \\
\hline
\end{tabular}

* Represents the diameter for circular columns and the length times the width of the square columns

$f_{f u}=$ The ultimate tensile strength of FRP bars

$E_{f}=$ The modulus of elasticity of FRP bars

$f_{c}^{\prime}=$ The compressive strength of the concrete 
Table 2: Comparison between the experimental and theoretical axial load carrying capacity of FRP bar reinforced concrete columns available in the previous research studies

\begin{tabular}{|c|c|c|c|c|c|c|c|c|c|}
\hline \multirow[t]{3}{*}{ Study } & \multirow[t]{3}{*}{ Specimen } & \multirow[t]{3}{*}{$\boldsymbol{P}_{\text {exp. }}{ }^{a}$} & \multicolumn{7}{|c|}{$P_{o} / P_{\text {exp. }}{ }^{b}$} \\
\hline & & & \multicolumn{6}{|c|}{ Eq. (8) } & \multirow{2}{*}{$\begin{array}{c}\text { Eq. (6) } \\
\text { Tobbi et al } \\
{[9]^{\mathrm{f}}}\end{array}$} \\
\hline & & & $\begin{array}{c}\text { Popovics } \\
{[23]^{\mathrm{c}, \mathrm{e}}}\end{array}$ & $\begin{array}{c}\text { Wee et al. } \\
{[24]^{\mathrm{c}, \mathrm{e}}}\end{array}$ & $\begin{array}{c}\text { Legeron and } \\
\text { Paultre }[25]^{\mathrm{c}, \mathrm{e}}\end{array}$ & $\begin{array}{c}\text { Yang et al. } \\
{[26]^{\mathrm{c}, \mathrm{e}}}\end{array}$ & $\begin{array}{l}\text { ACI 318- } \\
14[16]^{\mathrm{d}}\end{array}$ & $\begin{array}{c}\text { CSA A23.3- } \\
14[17]^{\mathrm{d}}\end{array}$ & \\
\hline \multirow{9}{*}{ Afifi et al [14] } & S-1 & 2905 & 0.95 & 0.95 & 0.96 & 0.96 & 0.99 & 1.01 & 1.05 \\
\hline & S-2 & 3148 & 0.91 & 0.92 & 0.93 & 0.93 & 0.97 & 1.00 & 1.07 \\
\hline & S-3 & 2948 & 0.97 & 0.98 & 0.99 & 0.99 & 1.04 & 1.07 & 1.14 \\
\hline & S-4 & 3070 & 0.93 & 0.94 & 0.95 & 0.95 & 1.00 & 1.03 & 1.10 \\
\hline & S-5 & 3013 & 0.95 & 0.96 & 0.97 & 0.97 & 1.02 & 1.05 & 1.12 \\
\hline & S-6 & 2981 & 0.96 & 0.97 & 0.98 & 0.98 & 1.03 & 1.06 & 1.13 \\
\hline & S-7 & 3147 & 0.91 & 0.92 & 0.93 & 0.93 & 0.97 & 1.00 & 1.07 \\
\hline & S-8 & 2941 & 0.97 & 0.98 & 1.00 & 0.99 & 1.04 & 1.07 & 1.15 \\
\hline & S-9 & 3107 & 0.96 & 0.97 & 0.99 & 0.99 & 1.05 & 1.09 & 1.19 \\
\hline \multirow{9}{*}{ Afifi et al [26] } & S-10 & 2826 & 0.93 & 0.93 & 0.94 & 0.94 & 0.95 & 0.96 & 0.99 \\
\hline & S-11 & 2951 & 0.90 & 0.91 & 0.92 & 0.92 & 0.94 & 0.96 & 1.03 \\
\hline & S-12 & 2857 & 0.93 & 0.94 & 0.95 & 0.95 & 0.97 & 0.99 & 1.06 \\
\hline & S-13 & 2964 & 0.90 & 0.91 & 0.92 & 0.92 & 0.94 & 0.95 & 1.03 \\
\hline & S-14 & 2920 & 0.91 & 0.92 & 0.93 & 0.93 & 0.95 & 0.97 & 1.04 \\
\hline & S-15 & 2804 & 0.95 & 0.96 & 0.97 & 0.97 & 0.99 & 1.01 & 1.08 \\
\hline & S-16 & 3019 & 0.89 & 0.89 & 0.90 & 0.90 & 0.92 & 0.94 & 1.01 \\
\hline & S-17 & 2865 & 0.94 & 0.94 & 0.95 & 0.95 & 0.97 & 0.99 & 1.06 \\
\hline & S-18 & 2998 & 0.90 & 0.92 & 0.93 & 0.93 & 0.96 & 0.98 & 1.09 \\
\hline \multirow{2}{*}{ Mohamed et al. [2] } & S-19 & 2840 & 0.95 & 0.95 & 0.96 & 0.96 & 0.98 & 1.00 & 1.07 \\
\hline & S-20 & 2871 & 0.94 & 0.94 & 0.95 & 0.95 & 0.97 & 0.98 & 1.06 \\
\hline
\end{tabular}


Table 2: (Continued)

\begin{tabular}{|c|c|c|c|c|c|c|c|c|c|}
\hline \multirow{4}{*}{ Mohamed et al. [2] } & S-21 & 2935 & 0.91 & 0.92 & 0.93 & 0.92 & 0.95 & 0.96 & 1.04 \\
\hline & $\mathrm{S}-22$ & 2869 & 1.00 & 1.01 & 1.02 & 1.02 & 1.07 & 1.10 & 1.18 \\
\hline & $\mathrm{S}-23$ & 2960 & 0.96 & 0.97 & 0.99 & 0.99 & 1.03 & 1.06 & 1.14 \\
\hline & S-24 & 3008 & 0.95 & 0.96 & 0.98 & 0.97 & 1.02 & 1.05 & 1.12 \\
\hline \multirow{4}{*}{ Karim et al. [31] } & S-25 & 1220 & 0.79 & 0.80 & 0.80 & 0.81 & 0.84 & 0.86 & 1.07 \\
\hline & S-26 & 1309 & 0.73 & 0.74 & 0.74 & 0.75 & 0.79 & 0.80 & 1.00 \\
\hline & S-27 & 1063 & 0.84 & 0.84 & 0.84 & 0.84 & 0.84 & 0.84 & 0.84 \\
\hline & $\mathrm{S}-28$ & 1170 & 0.77 & 0.77 & 0.77 & 0.77 & 0.77 & 0.77 & 0.77 \\
\hline Hales et al. [32] & S-29 & 7126 & 0.78 & 0.79 & 0.79 & 0.79 & 0.79 & 0.80 & 0.81 \\
\hline \multirow{2}{*}{ Hadhood et al. [15] } & S-31 & 4709 & 0.94 & 0.95 & 0.96 & 0.95 & 0.96 & 0.97 & 1.06 \\
\hline & S-32 & 4716 & 0.95 & 0.96 & 0.97 & 0.97 & 0.98 & 0.99 & 1.12 \\
\hline Hadhood et al. [33] & S-30 & 3090 & 0.82 & 0.83 & 0.84 & 0.84 & 0.91 & 0.94 & 0.99 \\
\hline \multirow{2}{*}{ Hadi et al. [16] } & S-33 & 2721 & 0.94 & 0.94 & 0.96 & 0.95 & 0.96 & 0.97 & 1.05 \\
\hline & S-34 & 2398 & 1.06 & 1.07 & 1.09 & 1.08 & 1.09 & 1.10 & 1.19 \\
\hline \multirow{4}{*}{ Tobbi et al. [13] } & S-35 & 4297 & 0.87 & 0.88 & 0.88 & 0.89 & 0.91 & 0.92 & 0.97 \\
\hline & S-36 & 4615 & 0.81 & 0.82 & 0.83 & 0.83 & 0.85 & 0.86 & 0.91 \\
\hline & S-37 & 4212 & 0.88 & 0.88 & 0.89 & 0.89 & 0.90 & 0.91 & 0.94 \\
\hline & S-38 & 3900 & 0.94 & 0.95 & 0.95 & 0.95 & 0.96 & 0.97 & 1.02 \\
\hline Mean & & & 0.91 & 0.92 & 0.93 & 0.93 & 0.95 & 0.97 & 1.05 \\
\hline SD & & & 0.068 & 0.068 & 0.071 & 0.070 & 0.076 & 0.082 & 0.096 \\
\hline
\end{tabular}


Table 2: (Continued)

\begin{tabular}{ccccccccc}
\hline COV $(\%)$ & 7.39 & 7.45 & 7.71 & 7.55 & 7.99 & 8.47 & 9.17 & 7.47 \\
MAPE & 9.642 & 9.305 & 8.614 & 8.612 & 7.542 & 7.478 & 9.692 \\
\hline
\end{tabular}

${ }^{\text {a }} P_{\text {exp. }}$ is the experimental axial load carrying capacity of FRP bar reinforced concrete columns.

${ }^{\mathrm{b}} P_{o}$ is the theoretically computed axial load carrying capacity of FRP bar reinforced concrete columns.

${ }^{\mathrm{c}}$ Refers to the formula used in computing $\varepsilon_{c o}$ (Eq. 9 - Eq. 12)

d equal to $\varepsilon_{c u}$ (0.003 or 0.0035 as defined in ACI 318-14 [20] and CSA A23.3-14[21], respectively).

e The contribution of the FRP longitudinal bars in $P_{o}$ was computed based on the formula defined in the footnote "c" above.

${ }^{\mathrm{f}}$ The contribution of the FRP longitudinal bars in $P_{o}$ was assumed to be equal to $0.35 f_{f u} A_{f}$ (Tobbi et al. [13]) 

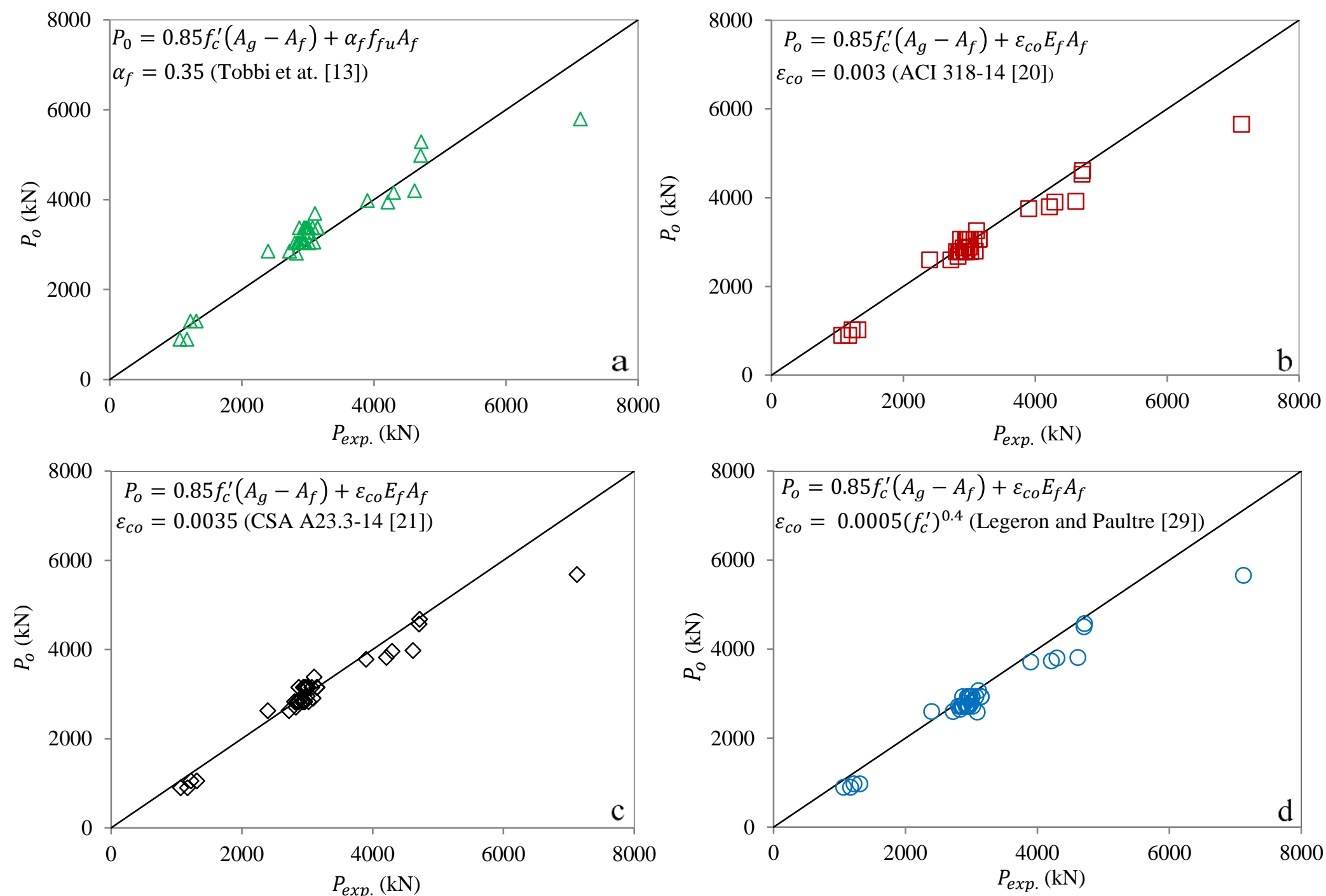

Fig. 1: Experimental versus predicted axial load carrying capacity of FRP bar reinforced concreter columns obtained using: a) Eq. $6\left(\alpha_{f}=0.35\right)$;

b) Eq. $8\left(\varepsilon_{c o}=0.003\right)$; c) Eq. $8\left(\varepsilon_{c o}=0.0035\right)$ and d) Eq. $8\left(\varepsilon_{c o}=0.005\left(f_{c}^{\prime}\right)^{0.4}\right)$. 

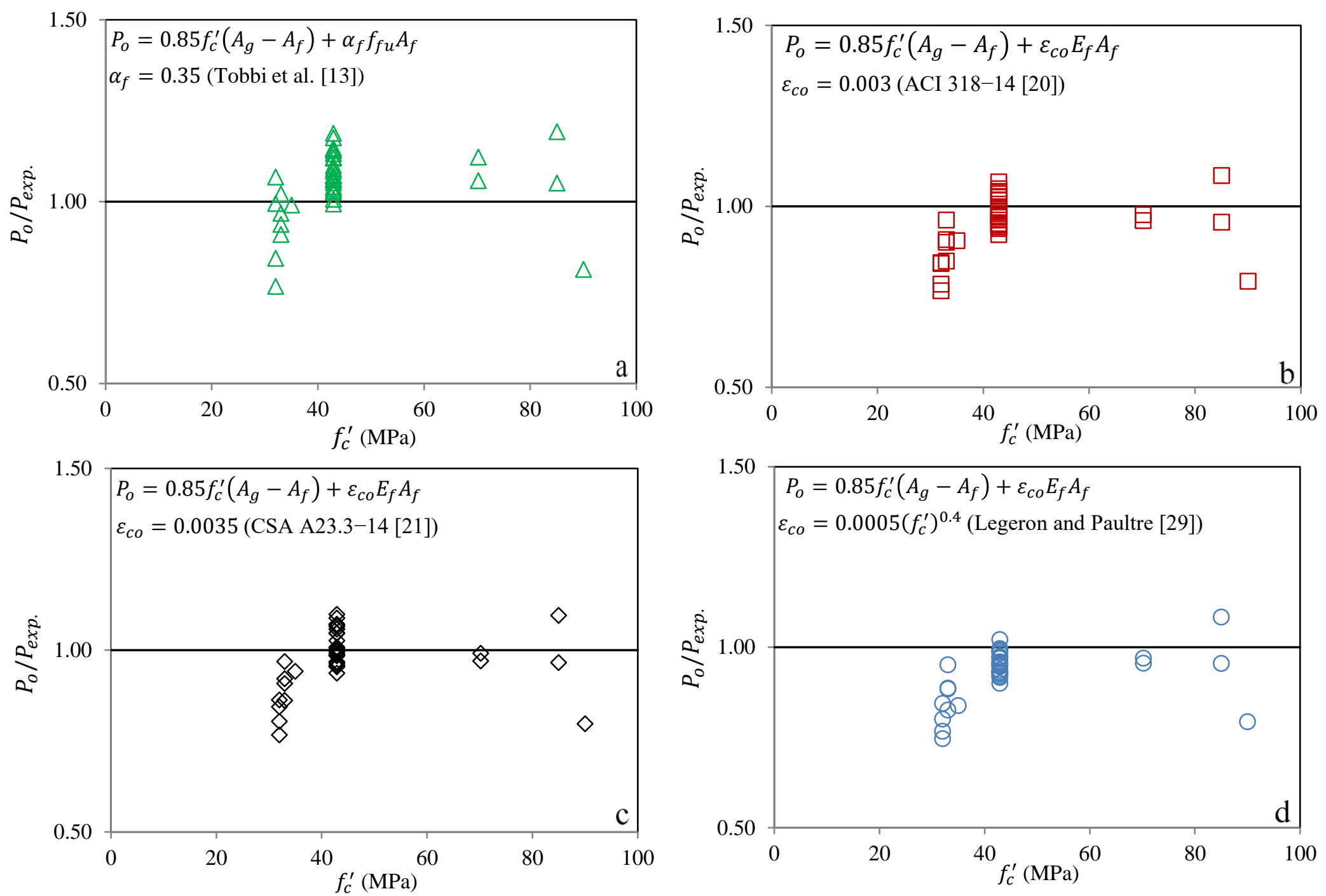

Fig. 2: The relationship between $P_{o} / P_{\text {exp. }}$ of the FRP bar reinforced concrete column and the compressive strength of the concrete $f_{c}^{\prime}$. Note: $P_{o}$ were obtained using: a) Eq. $6\left(\alpha_{f}=0.35\right)$; b) Eq. $8\left(\varepsilon_{c o}=0.003\right)$; c) Eq. $8\left(\varepsilon_{c o}=0.0035\right)$ and d) Eq. $8\left(\varepsilon_{c o}=0.005\left(f_{c}^{\prime}\right)^{0.4}\right)$. 